Agrovoc descriptors: heterorhabditis bacteriophora; identification; classification; indigenous organisms; insect nematodes; geographical distribution; biological control; pest control

Agris category code: $\mathrm{H} 10$

\title{
Heterorhabditis bacteriophora (Poinar) - the first member from Heterorhabditidae family in Slovenia
}

\author{
Žiga LAZNIK ${ }^{1}$, Tímea TÓTH ${ }^{2}$, Tamás LAKATOS ${ }^{3}$, Stanislav TRDAN ${ }^{4}$
}

Received: December 16, 2008; accepted: June 23, 2009.

Delo je prispelo 16. decembra 2008; sprejeto 23. junija 2009.

\begin{abstract}
In August 2008, we examined 95 soil samples for the occurrence of entomopathogenic nematodes in eastern part of Slovenia. 11 samples from 9 different locations were positive to entomopathogenic nematodes, but to this time only sample D54 was analysed. This soil sample was collected in Dravograd. Genetic studies proved that the nematode species in this sample was Heterorhabditis bacteriophora. This is the first record of Heterorhabditis nematode in Slovenia. Until now we confirmed the presence of four entomopathogenic nematode species in Slovenia; Steinernema affine, Steinernema carpocapsae, Steinernema feltiae and Steinernema kraussei. We expect that in Slovenia the use of these biological agents against insect pests will become important alternative to insecticides as it is known in many other countries of the world.
\end{abstract}

Key words: biological control, entomopathogenic nematodes, indigenous species, Slovenia, Heterorhabditis bacteriophora, Heterorhabditidae, first record

\section{IZVLEČEK \\ ENTOMOPATOGENA OGORČICA Heterorhabditis bacteriophora (Poinar) - PRVI PREDSTAVNIK IZ DRUŽINE HETERORHABDITIDAE, NAJDEN V SLOVENIJI}

V avgustu 2008 smo preučili 95 talnih vzorcev, da bi ugotovili zastopanost entomopatogenih ogorčic $\mathrm{v}$ vzhodnem delu Slovenije. 11 vzorcev $\mathrm{z}$ devetih različnih lokacij je bilo pozitivnih na zastopanost entomopatogenih ogorčic. Doslej smo analizirali le vzorec D54, ki je bil odvzet blizu Dravograda. Genetska analiza je potrdila, da gre za vrsto Heterorhabditis bacteriophora. Gre za prvo najdbo ogorčice iz rodu Heterorhabditis v Sloveniji. Doslej smo v Sloveniji potrdili zastopanost 4 vrst entomopatogenih ogorčic, in sicer: Steinernema affine, Steinernema carpocapsae, Steinernema feltiae in Steinernema kraussei. Pričakujemo, da bo $\mathrm{v}$ Sloveniji uporaba omenjenih naravnih sovražnikov škodljivih žuželk postala pomembna alternativa insekticidom, kar je sicer že znano v številnih drugih državah sveta.

Ključne besede: biotično varstvo, entomopatogene ogorčice, domorodna vrsta, Slovenija, Heterorhabditis bacteriophora, Heterorhabditidae, prva najdba

\footnotetext{
1 Young researcher, B. Sc., University of Ljubljana, Biotechnical Faculty, Department of Agronomy, Jamnikarjeva 101, SI-1111 Ljubljana, email:ziga.laznik@bf.uni-lj.si

2 Ph.D student, M. Sc., Vadastag 2, H-4244 Újfehértó, Hungary

3 Ph. D, Vadastag 2, H-4244 Újfehértó, Hungary

4 Assoc. Prof., Ph. D, Jamnikarjeva 101, SI-1111 Ljubljana
} 


\section{INTRODUCTION}

The entomopathogenic nematode Heterorhabditis bacteriophora was first described in 1975 as a new species as well as a member of new genus, and family (Heterorhabditidae) of Rhabditida (Poinar, 1976). The infective juvenile (IJ) stage was found to transmit a specific Gram-negative bacterium in the anterior intestine to the hemocoel of insect hosts (Poinar et al., 1977). This symbiotic bacteria is Photorhabdus luminescens subspecies luminescens (Fischer-Le Saux et al., 1999). Until now several Heterorhabditis species have been described (Adams et al., 2006) and studied for their biological control potential (Selvan et al., 1993; Koppenhöfer et al., 2004).

Transmission of symbiotic bacteria by the IJ of entomopathogenic nematodes is significant for EPN to successfully parasitize insect host and to reproduce (Han and Ehlers, 2000). This relationship can also be described as an obligate (for nematode and bacteria) vector-born disease of insects. It is discussed upon symbiotic-mutualistic relationship because nematodes provide shelter and protection for bacteria in an exchange for killing the attacked insects (Han and Ehlers, 2000). Latter, bacteria also produce antibiotics, which prevent the development of intra- and interspecific competitors ( $\mathrm{Hu}$ and Webster, 2000), which would also feed on cadavers. Bacteria transform the content of the host into feed, suitable for nematodes and also bacteria themselves are feed for nematodes (Kaya and Koppenhöfer, 1999).
Heterorhabditis bacteriophora life cycle includes an egg, four juvenile stages and the adult (Poinar, 1976). The third-stage juvenile is the only free-living form, which is able to attack and infect the insect. The infective third-stage juveniles move through the soil in search of an insect host. This stage is adapted to live without feeding for a prolonged time. When the host is found, the nematode can enter into it through natural openings, or uses a dorsal tooth or hook, to break the insect cuticle. After entrance the nematode releases the symbiotic bacteria (Milstead, 1979). The bacteria multiply in the insect hemocoel and in the period from 24 to 72 hours after the entrance of the entomopathogenic nematode insect usually dies (Ciche and Ensign, 2003).

In Slovenia, momentarily only two species of entomopathogenic nematodes, Steinernema feltiae and $S$. carpocapsae, have a status of indigenous species (MAFF, 2008ab); therefore only this species can be applied in the field. With the researches, which results we also present in this paper, we want to enlist as more species of entomopathogenic nematodes as it is possible, while in foreign countries they worth as alternatives to insecticides in controling pest insects (Schroer et al., 2005). The strain D54, which we present in a current paper, we plan to use in extensive experiments in the future; first in the laboratory and afterward, when its status will be administratively entrenched, also in the field.

\section{MATERIALS AND METHODS}

In August 2008, we examined 95 soil samples from 19 different locations on the occurrence of EPNs in Slovenia. The soil samples, five from each location, were taken in Prekmurje, Koroška and Štajersko region (eastern part of the country). We used »Galleria bait method «, which is the most frequently used method of EPNs detection from soil. After the death of greater wax moth (Galleria mellonella [Linnaeus]) larvae, we dried cadavers for 12 days and put them in so called $»$ White trap« (Bedding and Akhurst, 1975) to separate the nematodes from death larvae. The suspension, which was acquired in this way, was used for artificial infection of the larvae of greater wax moth. Following procedure contained the use of centrifuge and $5 \%$ concentration of sodium hypochlorate. The aim of this process was to acquire infective juveniles from the suspension. We confirmed the presence of nematodes in 11 soil samples from 9 locations. Only 1 positive sample, D54 (taken in the meadow near the city Dravograd (NW Slovenia, $46^{\circ} 35^{\prime} \mathrm{N}, 15^{\circ} 01^{\prime} \mathrm{E}, 390 \mathrm{~m}$ alt.) was identified to this time.

\section{RESULTS}

To confirm the identification of isolated nematodes from larvae of wax moth, a selected sample was analysed by molecular biological approach. Genomic DNA was extracted from individual nematode and PCR was performed to multiply ITS region using primers TW81 and AB28 after Hominick et al. (1997). PCR product were reisolated from $1 \%$ TAE-buffered agarose gel using QIAquick Gel Extraction Kit (Qiagen, USA) (Fig. 1). Reisolated sample was sequenced in the laboratory of the Agricultural Biotechnological Research Centre, Gödöllő, Hungary. The sequence was 


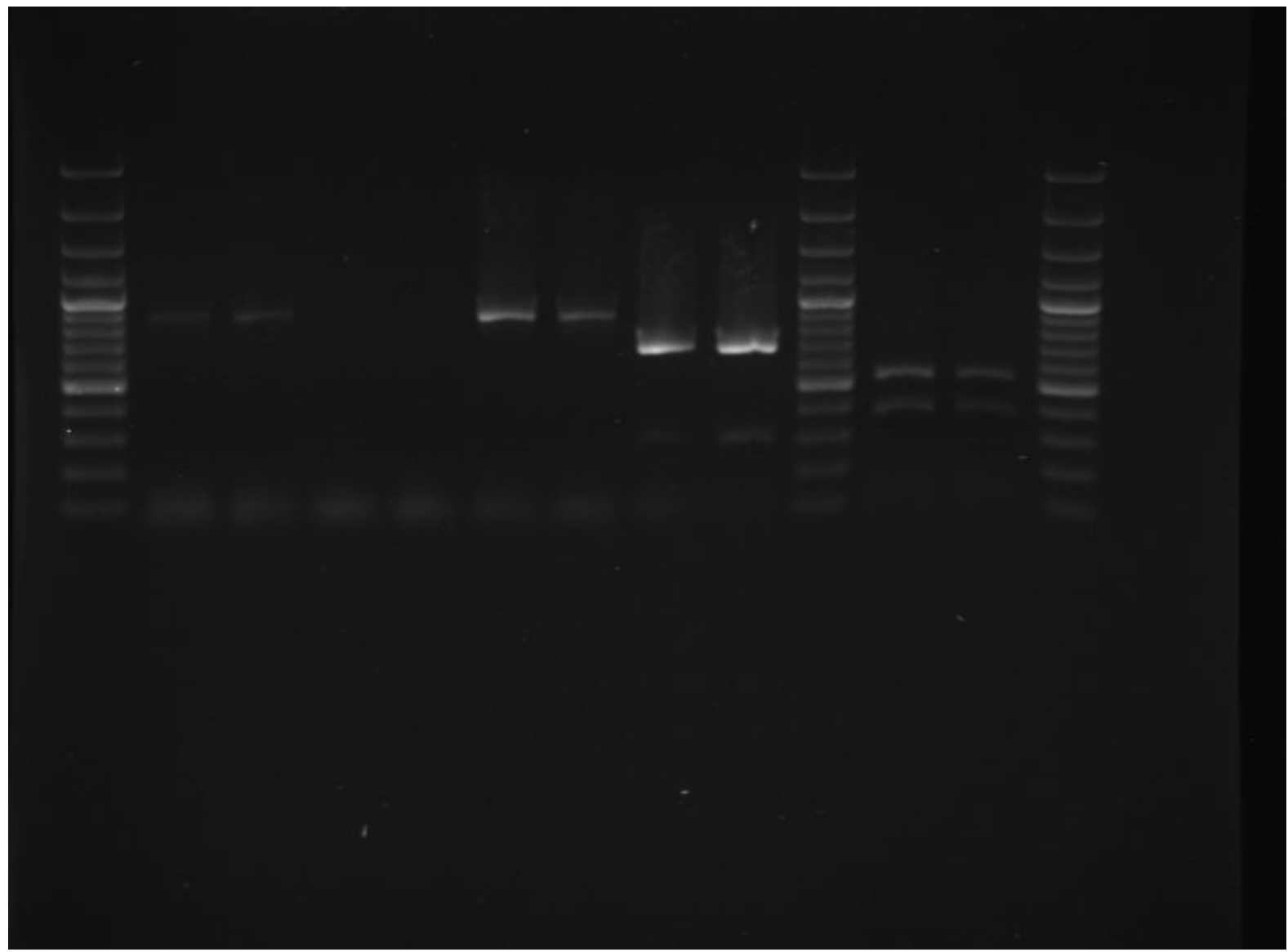

Figure 1: $1 \%$ TAE buffered agarose gel, in the $1^{\text {st }}, 10^{\text {th }}$ and $13^{\text {th }}$ lanes: GeneRuler 100 bp DNA Ladder Plus (Fermentas), in the $6^{\text {th }}$ and $7^{\text {th }}$ lane: PCR product of our sample D54, using the primer pair specified in the text, $8^{\text {th }}$ and $9^{\text {th }}$ lane: PCR product of sample slug nematode - Alloionema appendiculatum. The two most strength fragment in the ladder are 500 and 1000 bps length.

Sample DNA sequence was compared to sequences of species Heterorhabditis using BLAST search in National Centre for Biotechnology Information (NCBI) web site (www.ncbi.nlm.nih.gov). The sequences producing significant alignments and at least $99 \%$ identity were derived from Heterorhabditis bacteriophora: GenBank Accession No. FJ346825 and EU921445 (Fig. 2). 
Žiga LAZNIK in sod.

\begin{tabular}{|c|c|c|c|}
\hline FJ477060 & 1 & CGCCGA - AACCTTAT - - GGGT - AATGCTT - TG - AT - CACGAGAG - ATCGGTACCACT - GG & 51 \\
\hline FJ346825 & 100 & $\ldots \ldots-\ldots \ldots \ldots-\ldots \ldots-\ldots \ldots \ldots-\ldots-\ldots-\ldots \ldots \ldots-\ldots \ldots \ldots \ldots$ A. $-\ldots$ & 150 \\
\hline EU921445 & 1 & $\ldots-\ldots \ldots-\ldots-\ldots$ CC. $-\ldots \ldots \ldots-\ldots \ldots \ldots$ A. & 38 \\
\hline $\mathrm{EF} \odot 43440$ & 190 & $\ldots-\ldots \ldots \ldots-\ldots-\ldots \ldots$ T $-\ldots \ldots \ldots$ A. $-\ldots$ & 240 \\
\hline FJ47706 & 52 & - AAT - CAG - GCT - T - G - TTCTT - GATTT - C - AATCGGTTT - - CTCA - CCCCATCTAAGC & 98 \\
\hline FJ346825 & 151 & $-\ldots-\ldots-\ldots-,-\ldots \ldots-\ldots \ldots-, \ldots \ldots \ldots \ldots--\ldots \ldots-\ldots \ldots \ldots \ldots$ & 197 \\
\hline EU921445 & 39 & $-\ldots-\ldots-\ldots-,-\ldots \ldots-\ldots \ldots-, \ldots \ldots \ldots \ldots--\ldots \ldots-\ldots \ldots \ldots \ldots$ & 85 \\
\hline EF०43440 & 241 & $-\ldots-\ldots-\ldots-,-\ldots \ldots-\ldots \ldots-, \ldots \ldots \ldots--\ldots \ldots-\ldots \ldots$ & 287 \\
\hline FJ477060 & 99 & - TCAT - GGAG - A - GGTGT - CTAGT - CCCAAT - TGGAGTCGCTTTGAGTGA - C - GGCTAT - & 148 \\
\hline FJ346825 & 198 & $-\ldots \ldots-\ldots \ldots-,-\ldots \ldots-\ldots \ldots-\ldots \ldots-\ldots \ldots \ldots \ldots \ldots \ldots \ldots-\ldots-\ldots \ldots-$ & 247 \\
\hline EU921445 & 86 & $-\ldots \ldots-\ldots \ldots-, \ldots \ldots-\ldots \ldots-\ldots \ldots \ldots-\ldots \ldots \ldots \ldots \ldots \ldots \ldots-, \ldots \ldots \ldots-$ & 135 \\
\hline EF०43440 & 288 & $-\ldots \ldots-\ldots \ldots-\ldots \ldots-\ldots \ldots-\ldots \ldots-\ldots \ldots \ldots$ & 337 \\
\hline FJ477060 & 149 & G -AAAATTGGGTATG - - - T - TCCC - - CGTGAGGGTCGAGCATAGACTTTATGAACAGCT & 200 \\
\hline FJ346825 & 248 & ${ }_{-} \ldots \ldots \ldots \ldots \ldots--{ }_{-} \ldots{ }_{--} \ldots \ldots \ldots \ldots \ldots \ldots \ldots \ldots \ldots \ldots \ldots-$ & 298 \\
\hline EU921445 & 136 & 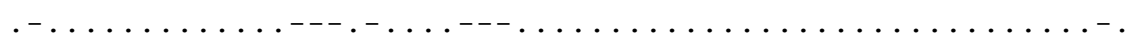 & 186 \\
\hline EF०43440 & 338 & $\ldots .-.$. & 388 \\
\hline FJ477060 & 201 & GCT - GG - AGCTGTCGCCTCACCAAAAAATCATC - GATAACT - GGTGGCTAT - G - TGTGAC & 254 \\
\hline FJ346825 & 299 & $\ldots-\ldots-\ldots \ldots \ldots \ldots \ldots \ldots \ldots \ldots \ldots \ldots \ldots-\ldots \ldots \ldots-\ldots \ldots \ldots \ldots-,-\ldots \ldots$ & 352 \\
\hline EU921445 & 187 & $\ldots-\ldots-\ldots \ldots \ldots \ldots \ldots \ldots \ldots \ldots \ldots \ldots \ldots-\ldots \ldots \ldots-\ldots \ldots \ldots \ldots-,-\ldots \ldots$ & 240 \\
\hline EF०43440 & 389 & $\ldots-\ldots-\ldots \ldots \ldots \ldots \ldots \ldots \ldots \ldots \ldots \ldots-\ldots \ldots G-\ldots \ldots \ldots-.-\ldots \ldots$ & 442 \\
\hline FJ477060 & 255 & ATT - AGTCACAT - AG - GTA - TC - TG - C - TGATGCAG - AGAG - CCTCTAATGAGTTGTT - - & 303 \\
\hline FJ346825 & 353 & $\ldots-\ldots \ldots \ldots-\ldots-\ldots-\ldots-\ldots-,-\ldots \ldots \ldots-\ldots \ldots-\ldots-\ldots \ldots \ldots \ldots \ldots--$ & 400 \\
\hline EU921445 & 241 & $\ldots-\ldots \ldots \ldots-\ldots-\ldots-\ldots-\ldots-,-\ldots \ldots \ldots-\ldots \ldots-\ldots-\ldots \ldots \ldots \ldots \ldots--$ & 288 \\
\hline EF०43440 & 443 & $\ldots-\ldots \ldots \ldots-T,-\ldots-\ldots-\ldots-. \ldots \ldots \ldots-\ldots \ldots-\ldots-\ldots \ldots \ldots \ldots--$ & 490 \\
\hline $\mathrm{FJ} 477060$ & 304 & C-GTGTCATC - TGACC - TACAA - CCGCCAG - TATCGGT - - AAA - T - C - - AACCCAA - TTA & 351 \\
\hline FJ346825 & 401 & $-\ldots \ldots \ldots \ldots-\ldots \ldots-\ldots \ldots-\ldots \ldots \ldots-\ldots \ldots \ldots-\ldots \ldots-,--\ldots \ldots \ldots-\ldots$ & 448 \\
\hline EU921445 & 289 & $-\ldots \ldots \ldots \ldots-\ldots \ldots-\ldots \ldots-\ldots \ldots \ldots-\ldots \ldots \ldots-\ldots \ldots-,--\ldots \ldots \ldots-\ldots$ & 336 \\
\hline EF०43440 & 491 & $-\ldots \ldots \ldots-\ldots \ldots-\ldots \ldots-\ldots \ldots c-\ldots \ldots \ldots-\ldots-,--\ldots \ldots \ldots-\ldots$ & 538 \\
\hline $\mathrm{FJ} 477060$ & 352 & ACTTGTTTC - T-TG - TGTCGTGT - TAATACATAC-TGGCA-AAGTGTATTAGCTTTAGCG & 405 \\
\hline FJ346825 & 449 & $\ldots \ldots \ldots \ldots-, \ldots-\ldots \ldots \ldots-\ldots \ldots \ldots \ldots-\ldots \ldots-\ldots \ldots \ldots \ldots \ldots \ldots \ldots$ & 502 \\
\hline EU921445 & 337 & $\ldots \ldots \ldots \ldots-{ }_{-}-\ldots \ldots \ldots-\ldots \ldots \ldots \ldots-\ldots \ldots-\ldots \ldots \ldots \ldots \ldots \ldots$ & 390 \\
\hline EF०43440 & 539 & $\ldots \ldots-\ldots-\ldots \ldots$ & 592 \\
\hline FJ477060 & 406 & ATGG - ATCGGTTGATTCGCGTATCGATGAAAAACGCAGCAAGC - - TGCGTTATTTACCAC & 462 \\
\hline FJ346825 & 503 & $\ldots{ }_{-\ldots \ldots \ldots \ldots \ldots \ldots \ldots \ldots \ldots \ldots \ldots \ldots \ldots \ldots \ldots--\ldots \ldots \ldots \ldots \ldots \ldots}$ & 559 \\
\hline EU921445 & 391 & $\ldots \ldots \ldots \ldots \ldots \ldots \ldots \ldots \ldots-\ldots \ldots \ldots$ & 447 \\
\hline EF०43440 & 593 & $\ldots \ldots \ldots \ldots-\ldots \ldots \ldots$ & 649 \\
\hline FJ477060 & 463 & GAATTGCAGACGCTTAGAGT - GGTGAAGTTTTGAACGCACAGCGCCGTTGGGTTTTCCCT & 521 \\
\hline FJ346825 & 560 & $\ldots \ldots \ldots \ldots \ldots \ldots \ldots \ldots-\ldots \ldots \ldots \ldots \ldots \ldots \ldots \ldots \ldots \ldots \ldots \ldots \ldots \ldots$ & 618 \\
\hline EU921445 & 448 & $\ldots \ldots \ldots-$ & 506 \\
\hline EF०43440 & 650 & $\ldots$ & 708 \\
\hline FJ477060 & 522 & TCGGCACGTCTGGCTCAGGGTTGTTTA-ATAAGCGAAAGTGTTGAAAGTTCATTAAACGA & 580 \\
\hline FJ346825 & 619 & $\ldots \ldots \ldots \ldots \ldots \ldots \ldots \ldots \ldots \ldots \ldots-1 \ldots \ldots \ldots \ldots \ldots \ldots \ldots \ldots \ldots \ldots \ldots \ldots \ldots \ldots$ & 677 \\
\hline EU921445 & 507 & & 565 \\
\hline EF०43440 & 709 & $\ldots G \ldots$. & 765 \\
\hline FJ477060 & 581 & GAGTTCGGTGATACTGACAACACTACGTCGAGCGGTGTACTGTTGAAAGTACCCCGTTCA & 640 \\
\hline FJ346825 & 678 & 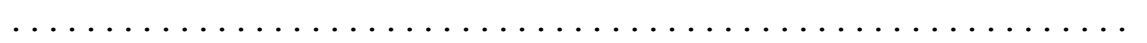 & 737 \\
\hline EU921445 & 566 & & 625 \\
\hline EF०43440 & 766 & 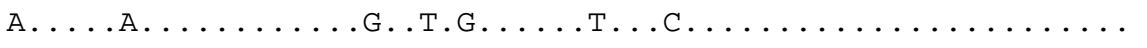 & 825 \\
\hline FJ477060 & 641 & AGTA- - TCTTTATGGGGCAACATGTCTTCTATATGGAGACATGAAAGATATTAAGAGTAT & 698 \\
\hline FJ346825 & 738 & 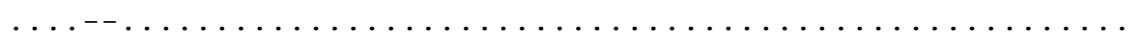 & 795 \\
\hline EU921445 & 626 & $\ldots$ & 683 \\
\hline
\end{tabular}


Heterorhabditis bacteriophora (Poinar) - the first member from Heterorhabditidae family in Slovenia

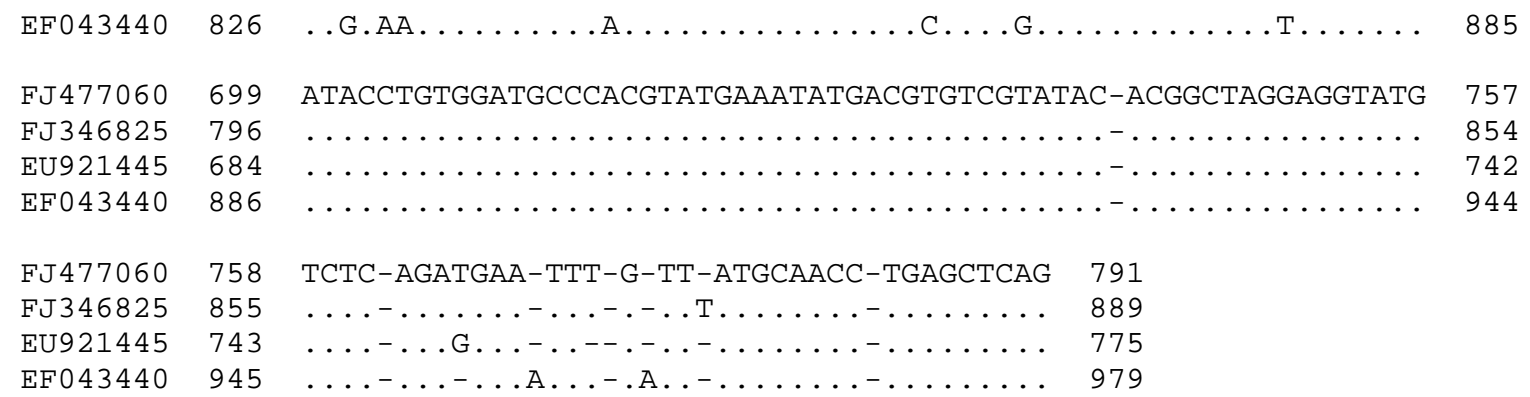

Figure 2: Multiple sequence alignment of the ITS rDNA region (including partial fragments of the $18 S$ and $28 S$ rDNA genes) of 4 Heterorhabditis species. Code FJ477060 correspond to the Slovenian isolate of Heterorhabditis bacteriophora (D54). Codes FJ346825 and EU921445 are Heterorhabditis bacteriophora strains from South Africa and Hungary. Code EFO43440 correspond to Heterorhabditis zealandica strain from Ireland.

\section{DISCUSSION}

Genetic studies proved that the nematode species is Heterorhabditis bacteriophora (Poinar, 1976) (Fig. 2). The ITS1-5.8S-ITS2 region, including the partial 18S and 28S rRNA genes (flanked by above primers) of Slovenian isolate D54, was 791 bp long (Fig. 1). BLAST searches (Altschul et al., 1990) in GenBank showed that Slovenian isolate D54 (Fig. 2) has a high similarity $(99 \%)$ with those sequences available for $H$. bacteriophora populations (e.g. accession numbers FJ346825 and EU921445). Sequence of other species from Heterorhabditis group, namely $H$. zealandica was obtained from GenBank searches that exhibited a lesser degree of similarity with the Slovenian isolate and other
H. bacteriophora populations (e.g. accesion number EFO43440) (Fig. 2). The present study constitutes the first report of $H$. bacteriophora in Slovenia. In Europe, the occurrence of $H$. bacteriophora was up to now confirmed in Bulgaria, Czech Republic, France, Germany, Hungary, Italy, Moldova, Poland, Portugal, Spain and Switzerland (Hominick, 2002). Only 4 species from genus Heterorhabditis were found in Europe; $H$. bacteriophora (11 countries), H. megidis (13 countries), $H$. downesi (3 countries) and $H$. zealandica (1 country) (Hominick, 2002).

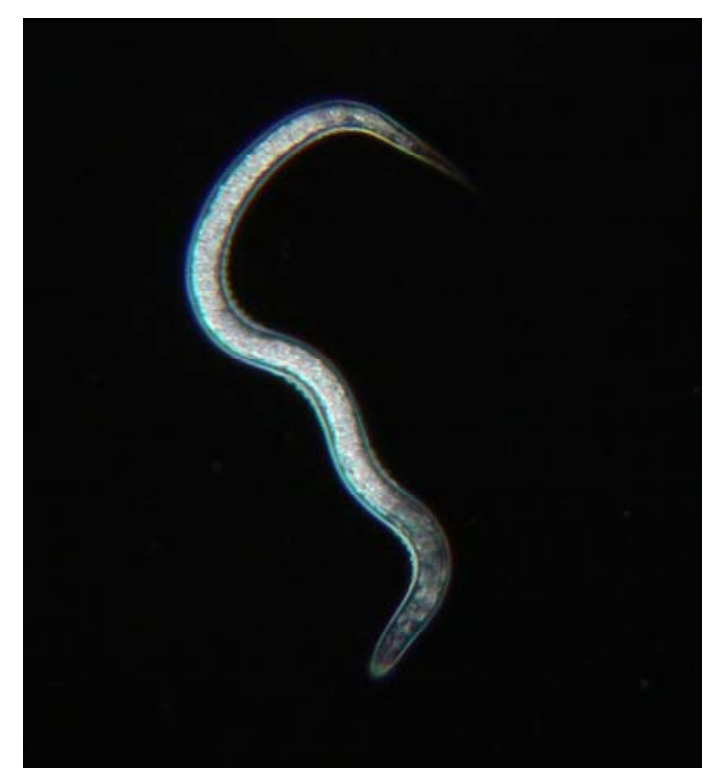

Figure 3: Infective juvenile (IJ) of Heterorhabditis bacteriophora from sample D54. 
The infective juveniles of $H$. bacteriophora are between 520 and $600 \mu \mathrm{m}$ long (Fig. 3). Entomopathogenic IJs developed different foraging behaviours to infect insect host, cruiser and ambusher strategies (Lewis et al., 1995). H. bacteriophora is a cruiser forager, meaning that it actively searches its host. In addition to sensing $\mathrm{CO}_{2}$ and volatile cues released by the host (O'Halloran and Burnell, 2002), IJs are attracted to ß-caryophyllene (Rasmann et al., 2005). This substance is a terpene, which is released, if the plant roots are damaged (Rasman et al., 2005). IJs developed chemosensory mechanisms not only to perceive the host, but also the locations where insect host are likely to be present.

$H$. bacteriophora IJs develop into hermaphrodites and this can lay eggs that develop into hermaphrodites, females or males. When the egg laying stops, nematodes can develop inside the maternal body with the process called endotokia matricida (Johnigk and Ehlers, 1999). Nematodes that are developed by endotokia matricida are predominantly hermaphroditic IJs (Dix et al., 1992).
Entomopathogenic nematode $H$. bacteriophora was proved to have big potential in biological control of insects (Selvan et al., 1993; Koppenhöfer et al., 2004). Some target pests that have been controlled by $H$. bacteriophora in field tests are white grubs, black vine weevil, strawberry root weevil, Colorado potato beetle, cucumber beetles and some others (Grewal et al., 2005). Some attempts have been made to test this nematode also against foliar pests, but the problem of desiccation, exposure to sunlight and high temperatures that are lethal to exposed nematodes have limited such applications (Grewal et al., 2005).

In Slovenia, momentarily only Steinernema feltiae and $S$. carpocapsae are on the domestic list and we are able to use them also in field experiments (Laznik et al., 2008ab). When also H. bacteriophora will shift from exotic agents list, we will test its activity against the pest insects in the open too. The most intensive experiments will be done against the insect pests for the control of which we do not have registered insecticides, their number is limited, and specially against the insects, which already developed the resistance to insecticides.

\section{ACKNOWLEDGEMENTS}

This work is a part of program Horticulture No P40013-0481 granted by Slovenian Research Agency, and the part of project CRP V4-0524 granted by Slovenian
Research Agency and Ministry of Agriculture, Food and Forestry of R Slovenia.

\section{REFERENCES}

Adams, B.J., Fodor, A., Koppenhofer, H.S., Stackebrandt, E., Stock, S.P., Klein, M.G. 2006. Biodiversity and systematics of nematode-bacterium entomopathogens. Biol. Contr. 37: 32-49.

Altschul S.F., Gish W., Miller W., Myers E.W., Lipman D.J. 1990. Basic local alignment search tool. J. Mol. Biol. 215: $403-410$.

Bedding R.A., Akhurst R.J. 1975. Simple technique for the detection of insect parasitic rhabditid nematodes in soil. Nematologica 21: 109-110.

Ciche, T.A., Ensign, J.C. 2003. For the insect pathogen Photorhabdus luminescens, which end of a nematode is out? Appl. Environ. Microbiol. 69: 1890-1897.

Dix, I., Burnell, A.M., Griffin, C.T., Joyce, S.A., Nugent, M.J., Downes, M.J. 1992. The identification of biological species in the genus Heterorhabditis nematode (Heterorhabditidae) by cross-breeding second generation amphimitic adults. Parasitology 104: 509-518.

Fischer-Le Saux, M., Viallard, V., Brunel, B., Normand, P., Boemare, N.E. (1999): Polyphasic classification of the genus Photorhabdus and proposal of new taxa: $P$. luminescens subsp. luminescens subsp. nov., $P$. luminescens subsp. akhurstii subsp. nov., $P$. luminescens subsp. laumondii subsp. nov., $P$. temperate sp. nov., $P$. temperate subsp. temperate subsp. nov and $P$. asymbiotica sp. nov. Int. J. Syst. Bacteriol. 49: 16451656.

Grewal, P.S., Ehlers, R.-U., Shapiro-Ilan, D.I. 2005. Nematodes as biocontrol agents. Wallingford, UK, CABI Publishing: 505 pp.

Han, R.C., Ehlers, R.-U. 2000. Pathogenicity, development and reproduction of Heterorhabditis bacteriophora and Steinernema carpocapsae under axenic in vivo conditions. J. Invertebr. Pathol. 75: 55-58.

Hominick W.M., Briscoe B.R., del Pino F.G., Heng J., Hunt D.J., Kozodoy E., Mracek Z., Nguyen K.B., Reid A.P., Spiridonov S., Stock P., Sturhan D., Waturu C., Yoshida M. 1997. Biosystematics of entomopathogenic nematodes: current status, protocols and definitions. J. Helminthol. 71: 271-298.

Hominick W.M. 2002. Biogeography. In: Gaugler R (ed) Entomopathogenic Nematology. CABI Publishing, Wallingford: 115-143. 
Hu, K., Webster, J M. 2000. Antibiotic production in relation to bacterial growth and nematode development in Photorhabdus-Heterorhabditis infected Galleria mellonella larvae. FEMS Microbiol. Lett. 189: 219-223.

Johnigk, S.-A., Ehlers, R.-U. 1999. Endotokia matricida in hermaphrodites of Heterorhabditis spp. And the effect of the food supply. Nematology 1: 717-726.

Kaya K.H., Koppenhöfer A.M. 1999. Biology and ecology of insectidal nematodes. In: Optimal use of insecticidal nematodes in pest management. Poravarapu S. (ed.). New Jersey, Bluberry Cranberry Research and Extension Center: 1-8.

Koppenhöffer, A.M., Fuzy, E.M., Crocker, R., Gelernter, W., Polavarapu, S. 2004. Pathogenicity of Steinernema scarabaei, Heterorhabditis bacteriophora and S. glaseri to twelve white grub species. Biocontrol Sci. Technol. 14: $87-92$

Laznik, Ž., Tóth, T., Lakatos, T., Trdan, S. 2008a. Entomopathogenic nematode Steinernema feltiae (Filipjev) (Rhabditida: Steinernematidae) recorded for the first time in Slovenia. Acta Agric. Slov. 91: 37-45.

Laznik, Ž., Tóth, T., Lakatos, T., Trdan, S. $2008 \mathrm{~b}$. Entomopathogenic nematode Steinernema carpocapsae (Weiser) (Rhabditida:Steinernematidae), a new member of Slovenian fauna. Acta Agric. Slov. 91: 351-359.

Lewis, E.E., Selvan, S., Campbell, J.F., Gaugler, R. 1995. Changes in foraging behaviour during the infective stage of entomopathogenic nematodes. Parasitology 110: 583590.

Ministry of Agriculture, Food, and Forestry of Republic Slovenia [MAFF]. 2008a: Decision on the change of the status of the exotic agent for biological control (no. 34309/2008/5): 2 p. [Slovenian]
Ministry of Agriculture, Food, and Forestry of Republic Slovenia [MAFF]. 2008b: Decision on the change of the status of the exotic agent for biological control (no. 3430583/2008/2): 2 p. [Slovenian]

Milstead, J.E. 1979. Heterorhabditis bacteriophora as a vector for introducing its associated bacterium into the homocoel of Galleria mellonella larvae. J. Invertebr. Pathol. 33: 324-327.

O'Halloran, D.M., Burnell, A.M. 2002. Olfaction and odour discrimination in the insect parasitic nematode Heterorhabditis bacteriophora. Nematology 4: 206.

Poinar, G.O.J. 1976. Description and biology of a new insect parasitic rhabditoid, Heterorhabditis bacteriophora $\mathrm{n}$. gen. n. sp. (Rhabditida: Heterorhabditidae n. fam.). Nematologica 21: 463-470.

Poinar, G.O.J., Thomas, G.M., Hess. R. 1977. Characteristics of the specific bacterium associated with Heterorhabditis bacteriophora (Heterorhabditidae: Rhabditida). Nematologica 23: 97-102.

Rasmann, S., Köllner, T.G., Degenhardt, J., Hiltpold, I., Toepfer, S., Kuhlmann, U., Gershenzon, J, Turlings, T.C.J. 2005. Recruitment of entomopathogenic nematodes by insect-damaged maize roots. Nature 434 : $732-737$.

Schroer, S., Sulistyanto, D., Ehlers, R.U. 2005. Control of Plutella xylostella using polymer-formulated Steinernema carpocapsae and Bacillus thuringensis in cabbage fields. J. Appl. Nematol. 129: 198-204.

Selvan, S., Gaugler, R, Campbell, J.F. 1993. Efficacy of entomopathogenic nematode strains against Popillia japonica (Coleoptera: Scarabaeidae) larvae. J. Econ. Entomol. 86: 353-359. 